\title{
История родственной группы кужугет из Барун-Хемчикского района Тувы
}

\author{
Шенне Ю. Кужугет \\ Тувинский государственный университет, Российская Федерация
}

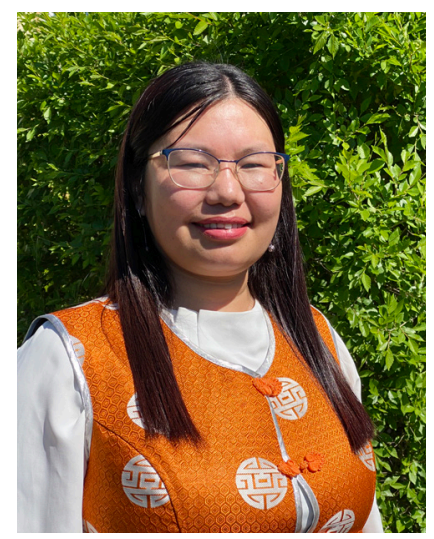

В статье представлено исследование по восстановлению родства тувинских родственных групп. Их история в ХХ веке была сложной и содержала разрывы связей. Автор рассказывает историю своей родственной группы кужугет по линии матери, которая была родом из с. Хонделен Барун-Хемчикского района. Представлено древо родственной группы кужугет, отмечены факты удочерения / усыновления, а также последствия паспортизации в Туве 1940-х г2.

Отдельно разобран вопрос о внутренней миграции (в пределах Тувы) членов родственной группы. На сегодня родственники проживают преимущественно в БарунХемчикском и Тандинском районах Тувы. Это наложило определенный отпечаток на поддержание родственных связей.

Рассмотрены вопросы укрепления связей (онлайн-формы общения), а также отмечена роль родовых обрядов, которые проводятся родственными группами в двух районах.

Ключевые слова: тувинцы; история Тувы; паспортизация; род; родственная группа; семейная обрядность; родословная; кужугет; хомушку

Подготовлено при финансовой поддержке Российского научного фонда в рамках научного проекта «Тезаурус этнической культуры в ХХІ веке: проблемы исследования и сохранения (на примере тувинской культуры)» (грант № 21-18-00246).

\section{Для цитирования:}

Кужугет Ш. Ю. История родственной группы кужугет из Барун-Хемчикского района Тувы // Новые исследования Тувы. 2021, № 4. С. 31-45. DOI: https://www.doi.org/10.25178/nit.2021.4.3

Кужугет Шенне Юрьевна - кандидат филологических наук, старший научный сотрудник лаборатории этнологии и лингвокультурологии, заведующая кафедрой педагогики и методики дошкольного и начального образования Тувинского государственного университета. Адрес: 667000, Россия, г. Кызыл, ул. Монгуша Сата, д. 9, лит. В, каб. 107. Тел.: +7 (923) 388-69-99. Эл. адрес: kuzhuget-sh@mail.ru

KUZHUGET, Shenne Yurevna, Candidate of Philology, Senior Researcher of the Laboratory of Ethnology and Linguoculturology; Head, Department of Pedagogy and Methods of Preschool and Primary Education, Tuvan State University. Postal address: Office 107, Letter B, 9 Mongusha Sata St., 667000 Kyzyl, Russian Federation. Tel.: +7 (923) 388-69-99. E-mail: kuzhuget-sh@mail.ru 


\title{
The History of the Kinship Group of Kuzhuget from the Barun-Khemchik District of Tuva
}

Article

\author{
Shenne Yu. Kuzhuget \\ Tuvan State University, Russian Federation
}

\begin{abstract}
The article presents an example of a study of the restoration of the relations between Tuvan kin groups whose history in the 20th century was turbulent and full of breaks in family ties. The author tells the story of her kin group of Kuzhuget on the side of her mother who was native to the village of Khondelen in the Barun-Khemchik district. The family tree of the kin group of Kuzhuget is presented and the facts of adoption are noted, as well as the consequences of passportization in Tuva in the 1940s.

The author in particular discusses the issue of the internal migration (within Tuva) among the members of the kinship group. Today the relatives live mainly in the Barun-Khemchik and Tandinsky districts of Tuva. This has had a certain influence on the maintenance of family ties.

The article examines the issues of the strengthening of relations (through online communication) and also notes the role of ancestral rites which are conducted by the kinship groups in the two districts.
\end{abstract}

Keywords: Tuvans; history of Tuva; passportization; lineage group; kinship group; family rite; family tree; Kuzhuget; Khomushku

\section{Financing}

The article was prepared with financial support from the Russian Science Foundation within the framework of the research project "Thesaurus of Ethnic Culture in the 21st Century: Problems of Study and Preservation (The Case of Tuvan Culture)" (grant No. 21-18-00246).

For citation:

Kuzhuget Sh. Yu. Istoriia rodstvennoi gruppy kuzhuget iz Barun-Khemchikskogo raiona Tuvy [The History of the Kinship Group of Kuzhuget from the Barun-Khemchik District of Tuva]. New Research of Tuva, 2021, no. 4, pp. 31-45. (In Russ.). DOI: https://www.doi.org/10.25178/nit.2021.4.3

\section{Введение}

С середины XX века одним из сегментов исследовательского поля проблем родства является изучение малых социальных групп, чаще всего выделенных по территориальному или этническому признаку. Такие группы могут выступать, с одной стороны, как локальные группы-сообщества, проживающие компактно, имеющие тесные связи и высокую степень групповой самоидентификации, а с другой стороны, как номинальные группы-категории, выделенные по этническому, религиозному, расовому или классовому принципу (Крецер, 2016). В этом русле интересно рассмотрение жизни родственных групп тувинцев как отдельных объектов исследования, тем более что тувиноведение преимущественно всегда занималось изучением в целом этноса или его субэтнических групп (тувинцев Монголии, Китая, красноярских тувинцев).

Тем не менее традиционно тувинцы жили родоплеменными, родовыми группами. Пока они имели общее место проживания и хозяйствовать, имели возможность постоянно общаться, то все знали родственников нынешних и предыдущих - старшие передавали информацию о них младшим. История рода пополнялась из поколения в поколение. Знать свою родословную хотя бы до чеди ада угу “кровного 
родства до седьмого колена' был обязан каждый тувинец. При этом М. Б. Кенин-Лопсан пишет, что в представлении о предках было важно знание и конкретики. В его книге есть термин тос ада угу 'девять поколений отцов', который представлен тремя основными видами: өгбелер 'предки’ (кровное родство до трех поколений), бурунгу өгбелер 'древние предки’ (родство от четвертого до шестого поколений), эрте-бурунгу өгбелер ‘далекие древние предки’ (родство от седьмого до девятого поколений) (КенинЛопсан, 1994: 53-54).

Однако, XX век существенно изменил социальную жизнь тувинцев. Родоплеменные группы распались, люди разъехались по всей Туве и за ее пределы (Ламажаa, 2021a: 124-125). В этих условиях знание родства, информацию о предках оказалось сложно и сохранять, и передавать. Сегодня восстановление этой информации сопряжено с целым рядом вопросов, связанных с отслеживанием соотношения истории рода и истории Тувы.

Я это покажу на примере восстановления истории родственной группы кужугет, членом которой являюсь я сама по линии матери. Важным аспектом исследования будет изучение влияния территориального признака на взаимоотношения и связи их членов (родственников). Соответственно для междисциплинарного исследования привлекаются методы как исторической, так и социальноантропологических наук.

Обсуждая родственную группу, я использую тувинский термин төрел бөлүк, который выражает общее название родственных групп. В моем случае речь идет о төрел бөлүк кужугет 'родственной группе кужугетов’.

Решаемые задачи: рассмотреть изученность отдельных аспектов темы, в том числе максимально восстановить по доступным источникам этническую историю рода кужугет; составить родословную группы кужугет; проанализировать влияние территориального признака на жизнь родственной группы, члены которой преимущественно проживают в Тандинском и Барун-Хемчикском районах, рассмотреть роль родового обряда дагылга; определить новые формы связи членов моей родственной группы.

Источниковую базу составили личные документы из домашнего архива моих родственников А. Д. Соян, записи в трудовых книжках А. Д. Соян, Д. Д. Монгуш, наградные документы А. Д. Хомушку, А. Д. Соян, воспоминания А. Д. Хомушку, семейные фотографии А. Д. Хомушку, А. Д. Соян, опрос и интервьюирование моих родственников А. Д. Хомушку, А. Д. Соян, Ал. Д. Хомушку, Ан. К. Кужугет. Также я опиралась на наблюдения родового обряда дагылга 2020-2021 гг., в которых принимала непосредственное участие. И, конечно, богатую пищу для анализа дают регулярные личные встречи, наблюдения за взаимоотношением моих родственников.

\section{Обзор литературы}

Объект и предмет моего исследования - этническая родственная группа, взаимоотношения ее членов - входят в поле внимания целого ряда научных дисциплин, а также позволяют проводить междисциплинарные исследования. Историю рода изучает историческая генеалогия, микроистория или локальная история, история повседневности (Пчелов, 2000; Старикова, 2021). Терминология родства находится в ведении филологии (Бурыкин, Попов, 2020). Системы родства, проблемы родственных отношений, феномен родства изучает антропология родства (Read, 2007, 2009; Миличич, 2010), а также этнография родства (Белков, 2013).

Общие исследования родоплеменного состава тувинцев проводились классиками советской этнографии С. И. Вайнштейном (Вайнштейн, 1959, 1969), Л. П. Потаповым (Потапов, 1969), а также тувинскими учеными, в частности М. Х. Маннай-оолом (Маннай-оол, 2004). Также этнографические исследования обогатились вниманием к субэтническим группам тувинцев (обзор основных исследований см.: Ламажаа, 2017).

С начала 1990-х гг. общий процесс национального возрождения в российских регионах выразился в широком обсуждении темы возрождения народных традиций, проведении мероприятий разного уровня, восстановлениях родовых идентичностей, практике усиления родоплеменных связей в разных формах (Ламажаа, Намруева, 2018). В тувиноведении это выразилось прежде всего в развитии филологических исследований - в терминологии родства (Кара-оол, 2004, 2006), в антропонимии (Сувандии, 2011). 
В тувиноведении изучение данной стороны социальной жизни было сосредоточено на ее традиционном состоянии в дореволюционную эпоху (в форме этнографического описания родоплеменных структур (Яковлев, 1900; Кон, 1934; Вайнштейн, 1959, 1969; Потапов, 1969; Маннай-оол, 2004; Прокофьева, 2011), на вопросах ее трансформации в советский период (для фиксации изживания старых форм и прогрессивных изменений в семейном быту (Вайнштейн, 2009; Кужугет, 2016; Биче-оол, 2018). В постсоветское время эта тема практически не исследовалась, хотя было признано, что социокультурные процессы в Туве имеют значительный характер архаизационных и неотрадиционалистских тенденций (Ламажаа, 2013). И при этом родовые связи и родовые отношения остались важными для тувинцев (Кужугет и др., 2019).

Этот исследовательский пробел не присущ только тувиноведению. Как пишет И. Ю. Крецер, изучение родства в собственном обществе, которое становится полноправной частью современных социальных исследований и «постоянно ускользают от исследовательского взгляда, особенно когда мы приступаем к изучению собственного общества» (Крецер, 2016: 167).

Таким образом, я попытаюсь восполнить пробел в данном направлении, разумеется, обращаясь только к истории и особенностям социальной жизни одной из тувинских родственных групп.

\section{История этнического расселения кужугет}

Несмотря на отсутствие исследований по отдельным родоплеменным группам тувинцев, упоминания о каждой из них присутствуют в литературе. Так, история родоплеменной группы кужугетов входила в поле внимания историков, этнографов, филологов и экологов (Потапов, 1969; Маннай-оол, 2004; Татаринцев, 2009; Чистик, 2010; Прокофьева, 2011; Дыртык-оол, Хертек, 2018).

Как писал Л. П. Потапов, первые сведения о кучугутах (кужугетах) появляются в исторических источниках с 1615 г. (Потапов, 1969: 21). На карте С. Ремезова, отражающей расселение народов Сибири к концу XVII в., отмечены группы саянов, живших в Саянских горах, здесь же жило и тувинское племя, именуемое в русских исторических документах кучугутами, кученгутами. Л. П. Потапов в своей работе подчеркнул, что ближайшие исторические предки группы современных тувинцев, называли себя кужугетами (там же: 21).

По сведениям М. Маннай-оола, кужугеты кочевали по Горному Алтаю и Верхнему Приобью вместе с другими племенами (ооржаками (оорчаки), кара-салами (керсагальцы), саянцами (верхние саянцы, саяны), кужугетами (кучугуцкие черные калмыки), тоджинцами (точи), мингатами (мунгаты)), одновременно поддерживая связь с алтайскими телеутами (Маннай-оол, 2004: 99).

Кужугеты входили в Бээзи хошун (совр. Барун-Хемчикский район), где числились сумоном, у них было 150 или 186 юрт. Кочевали в основном о долине Алаша и в окрестностях оз. Кара-Холь (там же: 73). В период маньчжурского господства в Туве племена кужугетов совместно с хомушку перекочевывали в местности Хонделен и по р. Барлык, и входили в состав Бээзи хошуна. Кужугеты жили смешанно с ооржаками, хомушку по р. Алаш (там же: 113).

Происхождение этнонима кужугет связано с тотемистическими представлениями: в нем можно видеть отражение названия обожествляемого животного, считающегося родоначальником племени, которое отражение тотема типа кужуген (Татаринцев, 2009: 168).

Так, я предполагаю, что история моей родственной группы, рассматриваемой мною, восходит к тем же кужугетам, которые жили в окрестностях р. Алаш, озера Кара-Холь и м. Устуу-Шыдаяк БарунХемчикского района.

\section{История моей родственной группы кужугет}

Как отмечает Ш. Степанофф, для многих молодых тувинцев, родившихся после 1980-х годов, характерно приписывать себе больше общего с аймаком матери в том, что касается черт характера и социальных связей (Степанофф, 2009). То же характерно и для моего случая - я отношу себя $\mathrm{K}$ родственной группе кужугет по материнской линии, так как тесно общаюсь с родственниками матери. Тем не менее надо сказать, что и по линии отца мы тоже относимся к этой же группе кужугет, он родился в м. Кызыл-Тайга Барун-Хемчикского района. Я выяснила, что мои родители жили и росли практически на одной территории в долинах р. Алаш, оба носили фамилию Кужугет.

Далее я привожу схему генеалогического древа төрел бөлүк кужугет по линии матери (рuс. 1) 
НОВЫЕ ИССЛЕДОВАНИЯ ТУВЫ

www.nit.tuva.asia
THE NEW RESEARCH OF TUVA

Novye issledovaniia Tuvy

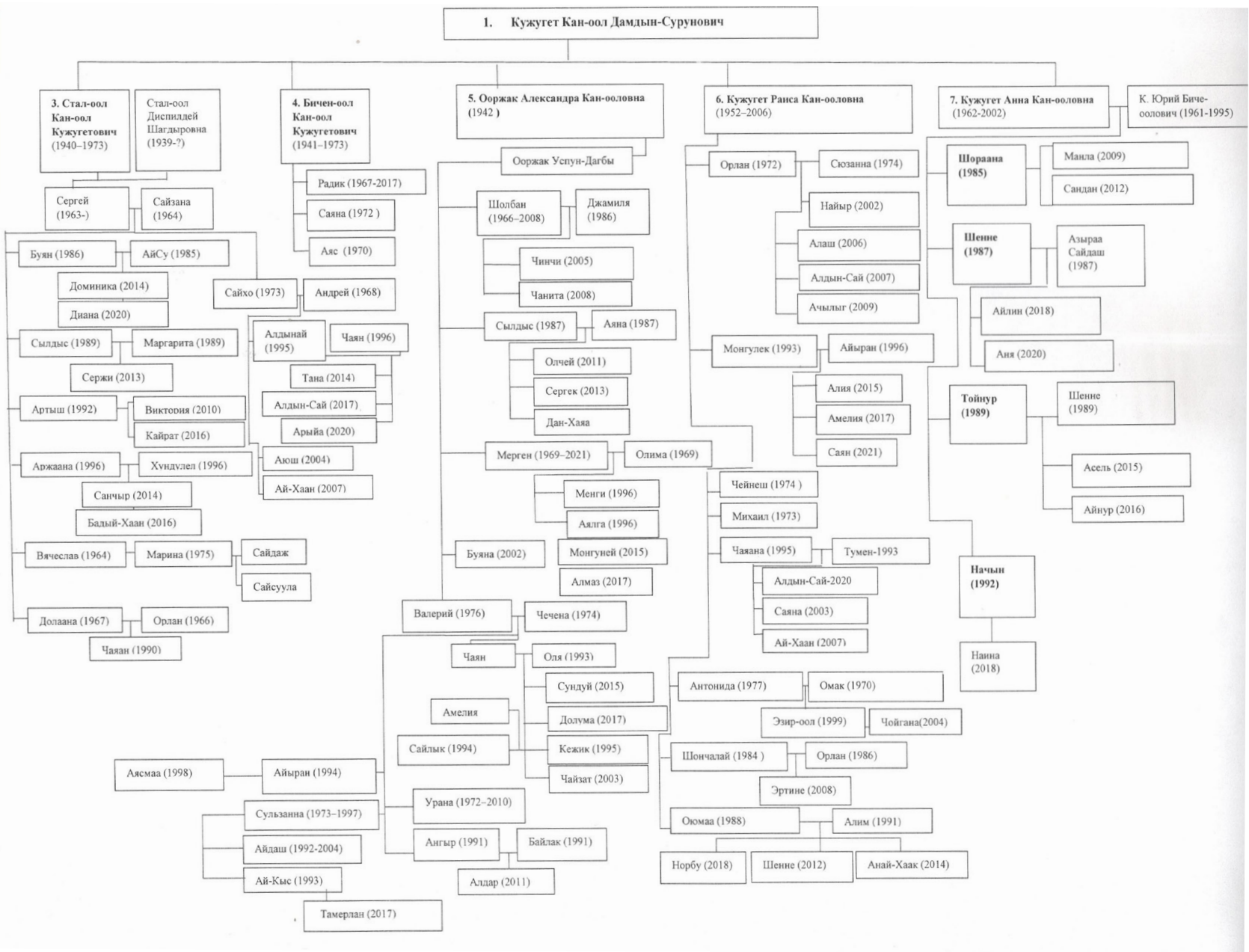

Рис. 1. Генеалогическое древо төрел бөлүк кужугет Барун-Хемчикского района. Составлено автором.

Fig. 1. The genealogical tree of the terel belyk Kuzhuget of the Barun-Khemchik district. Compiled by the author.

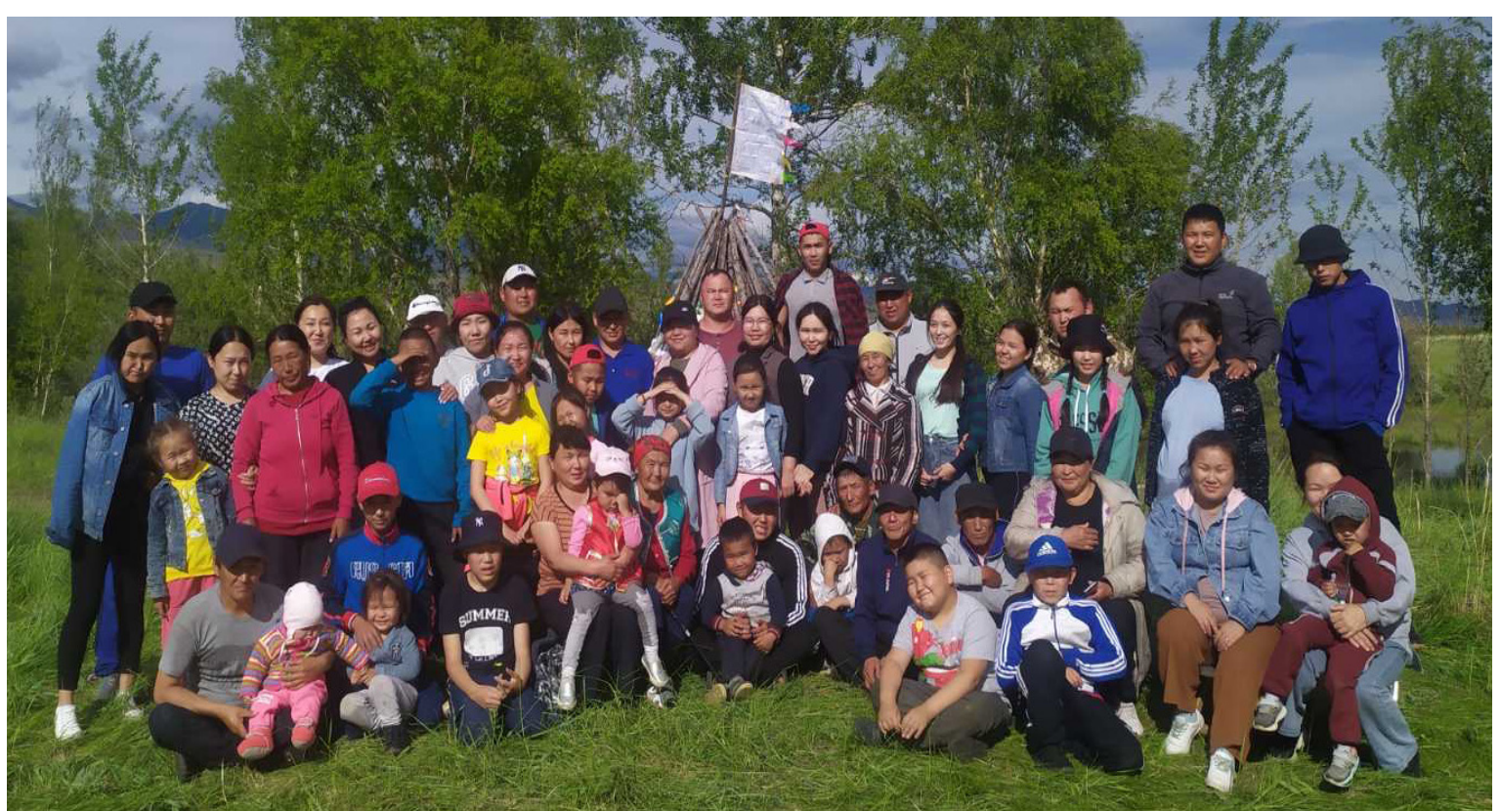

Фото 1. Родственная группа кужугет. Фото Ч. Ооржак, 2021 г.

Photo 1. The kinship group of Kuzhuget. Photo by Ch. Oorzhak, 2021. 
В приведенном на рис. 1 генеалогическом древе отсчет родственников в истории моей родственной группы Кужугет ведется от предка - дедушки по имени Кужугета Кан-оола Дамдын-Суруновича ${ }^{1}$ (годы жизни неизвестны; 1 на рис. 1). Он является воспитавшим отцом моей матери (т. е. он мой дедушка по маме), которую он удочерил. Он всю жизнь был чабаном в местностях Ак, Алаш, УстууШыдаяк Барун-Хемчикского района. У него было шестеро детей: самый старший сын Хомушку Доржу (по прозвищу Доржубал) Бак-Караевич (2 на рис. 2) был усыновлен в семью дедушки Кужугета Каноола, поэтому у него другие фамилия и отчество. Стал-оол Кан-оол Кужугетович (1940-1973) (3 на рис. 1), фамилия и имя были изменены в период внесения данных в паспорт, Бичен-оол Кан-оол Кужугетович (1941-1973) (4 на рис. 1), тоже фамилия и имя изменены при паспортизации, дочери Ооржак Александра Кан-ооловна (род. 04.03.1942 г.; девичья фамилия Кужугет) (5 на рис. 1), Кужугет Раиса Кан-ооловна (1952-2006) (6 на рис. 1) и моя мама, Кужугет Анна Кан-ооловна (1962-2002) (7 на рис. 1), удочеренная из другой семьи (см. далее).

Мне и моим родственникам - С. Х. Кара-Сал, А. К. Кужугет, Ч. В. Ооржак, Ч. К. Шавы - удалось собрать сведения на 5 поколений потомков от предка с общим количеством 109 человек. Всего на древе указано 36 семей.

Так как моя мама была удочерена, далее привожу продолжение древа семьи родного отца моей мамы.

На древе рис. 2 отсчет ведется от Хомушку Доржу Бак-Караевича (1935-1983), который приходится родным отцом моей матери и усыновленным старшим сыном Кужугета Кан-оола Дамдын-Суруновича (1 на рис. 1) Он всю жизнь был чабаном, пас яков в той же местности, что и приемный отец моей мамы. Всего у него было четверо детей с первой женой Хомушку Кертик Коковной (1935-1963): Александр Доржуевич Хомушку (08.01.1957 г.р.) (8 на рис. 2), Алефтина Доржубаловна Соян (девичья фамилия Хомушку) (16.12.1958 г.р.) (9 на рис. 2), Александра Доржуевна Куулар (девичья фамилия Хомушку) (12.08.1960 г.р.) (10 на рис. 2). После смерти первой жены Хомушку Кертик Коковны (1935-1963) Хомушку Доржу вскоре женился во второй раз на Хомушку Рузе Борашовне (1935-1990), и в браке у них родились 6 детей: Аркадий Доржуевич Хомушку (27.09.1963 г.р.) (11 на рис. 2), Нина Доржуевна Сарыглар (девичья фамилия Хомушку) (30.12.1965 г.р.) (12 на рис. 2), Игорь Доржуевич Хомушку (10.02.1967 г.p.) (13 на рис. 2), Долаана Доржуевна Монгуш (девичья фамилия - Хомушку) (30.05.1969 г.p.) (14 на рис. 2), Чойганмаа Доржуевна Хомушку (1973-2018) (15 на рис. 2), Саида Доржуевна Хомушку (11.08.1975 г.p.) (16 на рис. 2).

Это древо состоит из 4 поколений с общим количеством 83 чел. Всего на древе отражена 21 семья. Для составления данной схемы мне помогали члены данной родственной группы А. Д. Хомушку, А. Д. Соян, С. Д. Хомушку, Д. Д. Монгуш, А. А. Сарыглар.

Таким образом, моя мама имела родных и приемных родителей, которые представляли родственные группы - кужугетов и хомушку.

Дальнейшее восстановление родословных сталкивается с фактором паспортизации, которая была проведена в Туве в связи с вхождением ее в состав СССР (1944 г.). Для получения советских паспортов тувинцам необходимо было вносить свои сведения по русифиционной формуле «фамилия, имя и отчество». А поскольку у тувинцев отчеств не было, называлось только имя отца, не было и фамилий (был общий род), то им приходилось «изобретать» каждому человеку себе фамилию и порой имя. Как потом отметила Н. Д. Сувандии, «в тувинском языке отмечаются фамилии, также образованные от имен их носителей, а родоплеменное название (фамилия) в данном случае становится именем» (Сувандии, 2011: 51).

Так, сыновья дедушки Кужугета Кан-оола Дамдын-Суруновича, Стал-оол Кан-оол Кужугетович (1940-1973) и Бичен-оол Кан-оол Кужугетович (1941-1973) при оформлении паспортов взяли свои имена как фамилии, а имя отца - как имя собственное, а фамилию - как отчество. Поэтому будучи родными братьями, по документам они таковыми не являются.

Дети Хомушку Доржу Бак-Караевича носят отчество Доржуевна и Доржуевич, кроме моей тети Алефтины Доржубаловны, которая носит как отчество прозвище своего отца. Из воспоминаний моей тети А. Д. Соян, об этом попросил ее сам отец.

\footnotetext{
${ }^{1}$ В воспоминаниях моих родных он именовался по-русски - с фамилией и данным отчеством, хотя, очевидно, что он имел тувинское имя.
} 


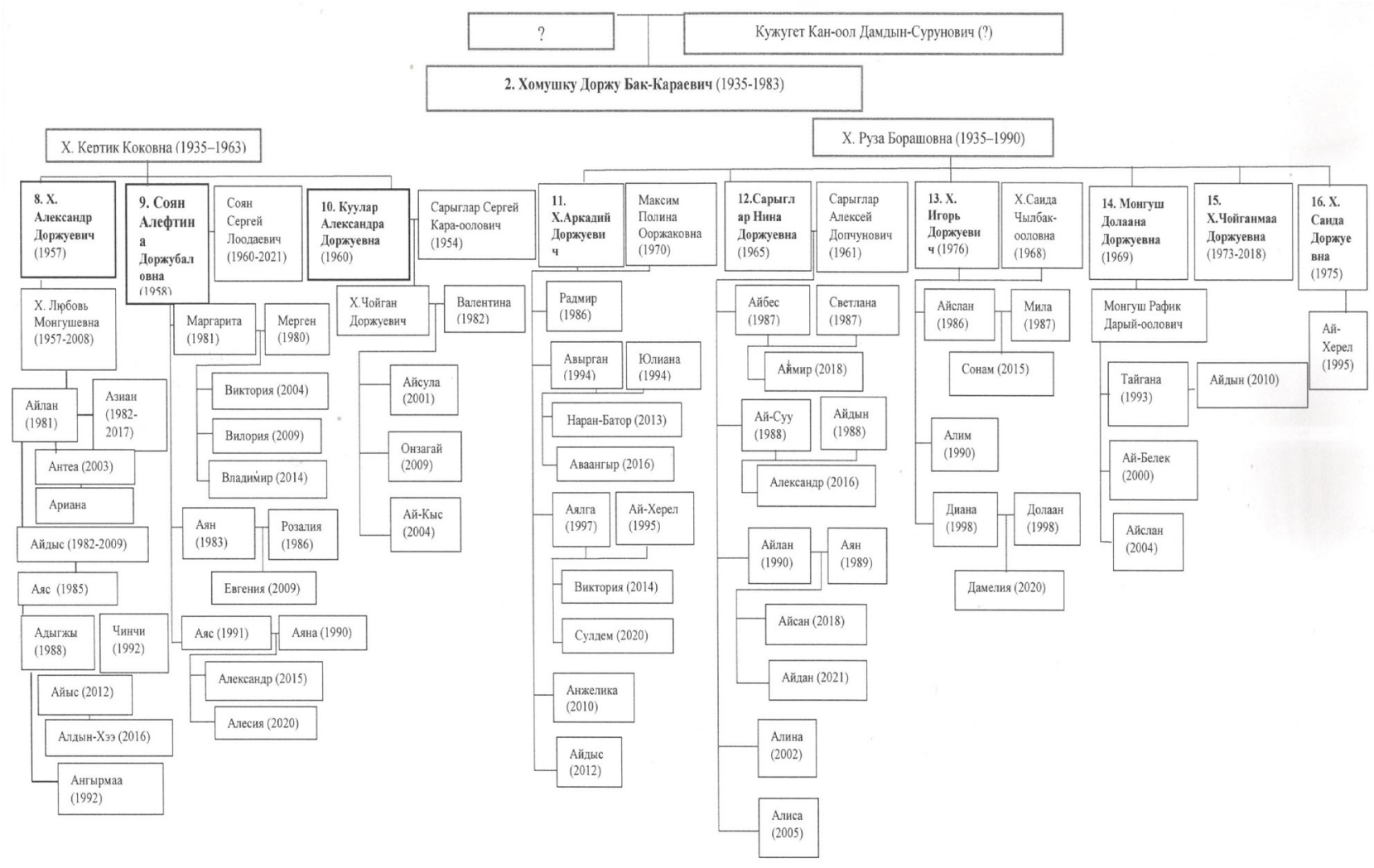

Рис. 2. Генеалогическое древо төрел бөлүк хомушку Барун-Хемчикского района. Составлено автором. Fig. 2. The genealogical tree of the terel belyk Khomushku of the Barun-Khemchik district. Compiled by the author.

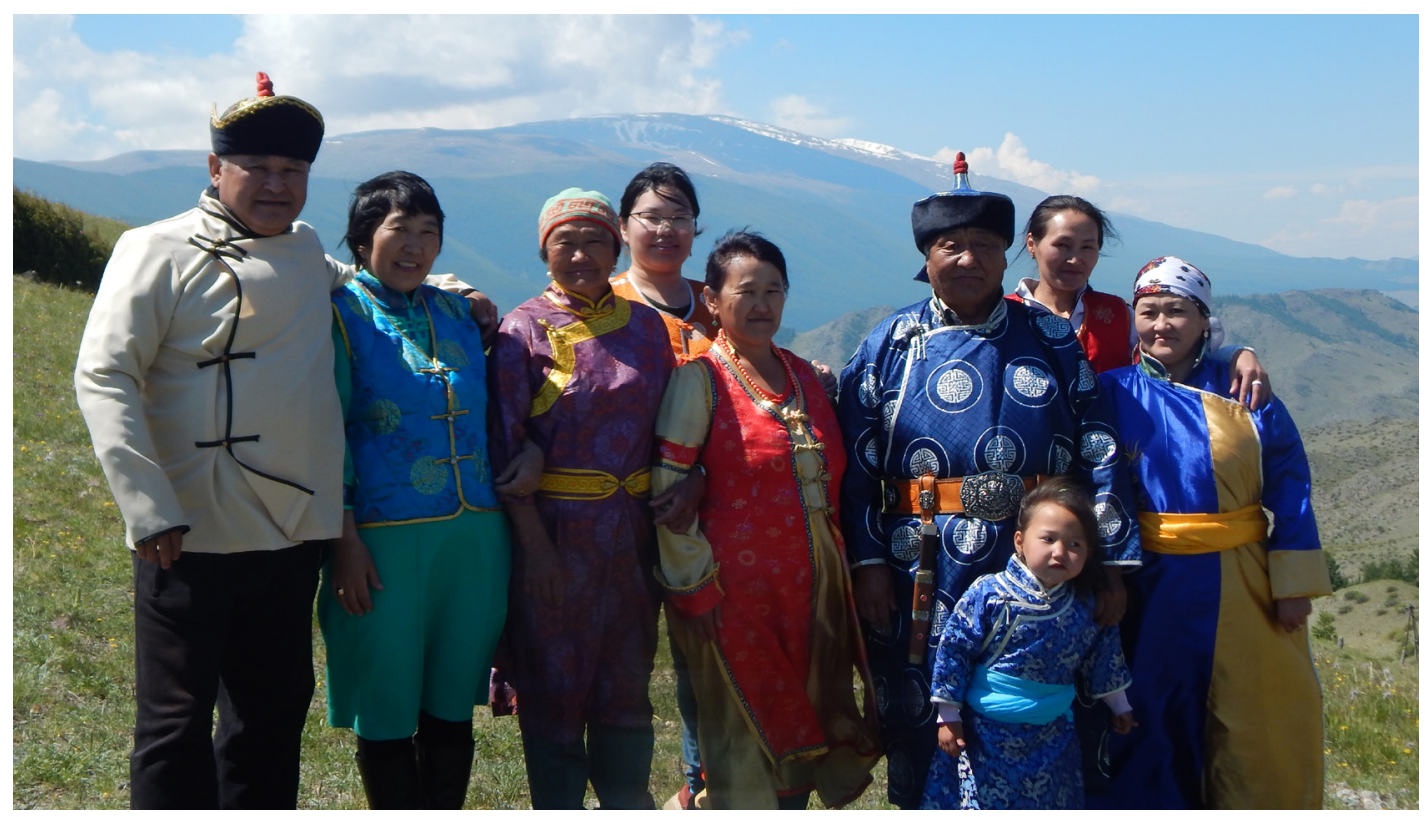

Фото 2. Представители родственной группы хомушку. Фото А.-Б. Монгуш, 2021 г.

Photo 2. Representatives of the kinship group of Khomushku. Photo by A.-B. Mongush, 2021. 
В настоящее время из родных детей нашего общего предка Кужугета Кан-оола Дамдын-Суруновича, не считая приемного сына Хомушку Доржу Бак-Караевича, сформировались три родовые фамилии: Кужугет, Бичен-оол, Стал-оол. Последняя группа Бичен-оол (21 чел.) и Стал-оол (25 чел.) тем не менее, относят себя к роду кужугет. Я себя отношу к многочисленной группе кужугет, так как общий предок нашего рода кужугет.

\section{территории}

Если исконной территорией обитания членов рода кужугет был Барун-Хемчикский район, то впоследствии төрел бөлүк кужугет стал проживать сразу в двух районах - Барун-Хемчикском и Тандинском, куда переехали мои тети с семьями, а затем и мои родители. В 1987-1988 гг. сестры из приемной семьи моей мамы Александра Кан-ооловна Ооржак и Раиса Кан-ооловна Кужугет со своими семьями переехали из поселка Кызыл-Мажалык БарунХемчикского района на постоянное место жительства в совхоз «50 лет СССР» села Межегей Тандинского района.

Причиной для смены места жительства моих родственников был поиск нового места работы. С 1950-х гг. в Туве началось существенное организационно-хозяйственное укрепление колхозов, происходили значительные качественные изменения, росла площадь пашни и урожайность сельскохозяйственных культур, поголовье скота и его продуктивность; осуществлялся массовый перевод колхозников на оседлый образ жизни, менялся социальный облик сел. И совхозы на начало 1982 г. представляли собой крупные сельскохозяйственные предприятия (Очерки социального ..., 1983: 32). Мои тети с мужьями смогли трудоустроиться животноводами в совхозе с. Межегей.

В начале 1990-х гг. туда за ними переехала и семья моих родителей, с нами - детьми. В с. Кызыл-Мажалык мой отец, Кужугет Юрий Биче-оолович (17.08.1961-10.06.1995), работал на мясокомбинате, стал трудиться животноводом - сначала в совхозе

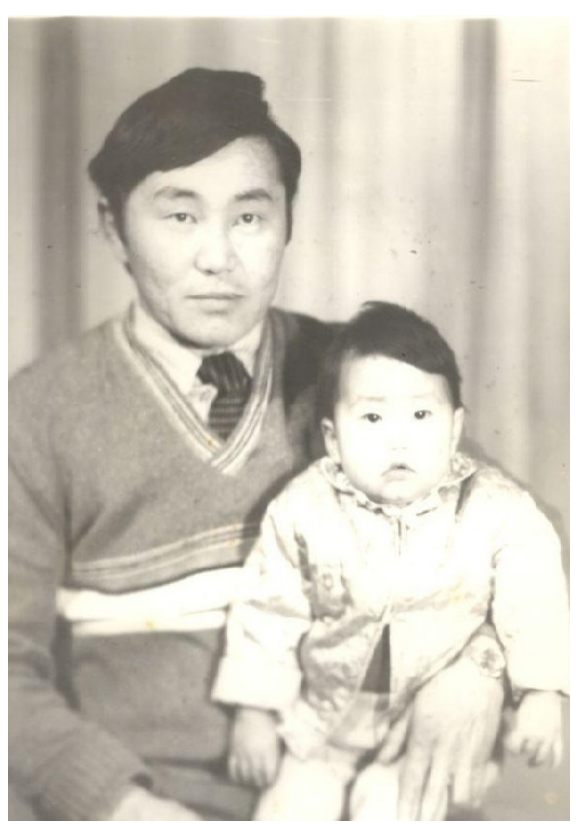

Фото 3. Ш. Ю. Кужугет, автор статьи, с отцом. 29.11.1988 г. Фото из личного архива автора.

Photo 3. Sh. Yu. Kuzhuget, the author of the article, with her father. November 29, 1988, Photo from the author's personal archive.

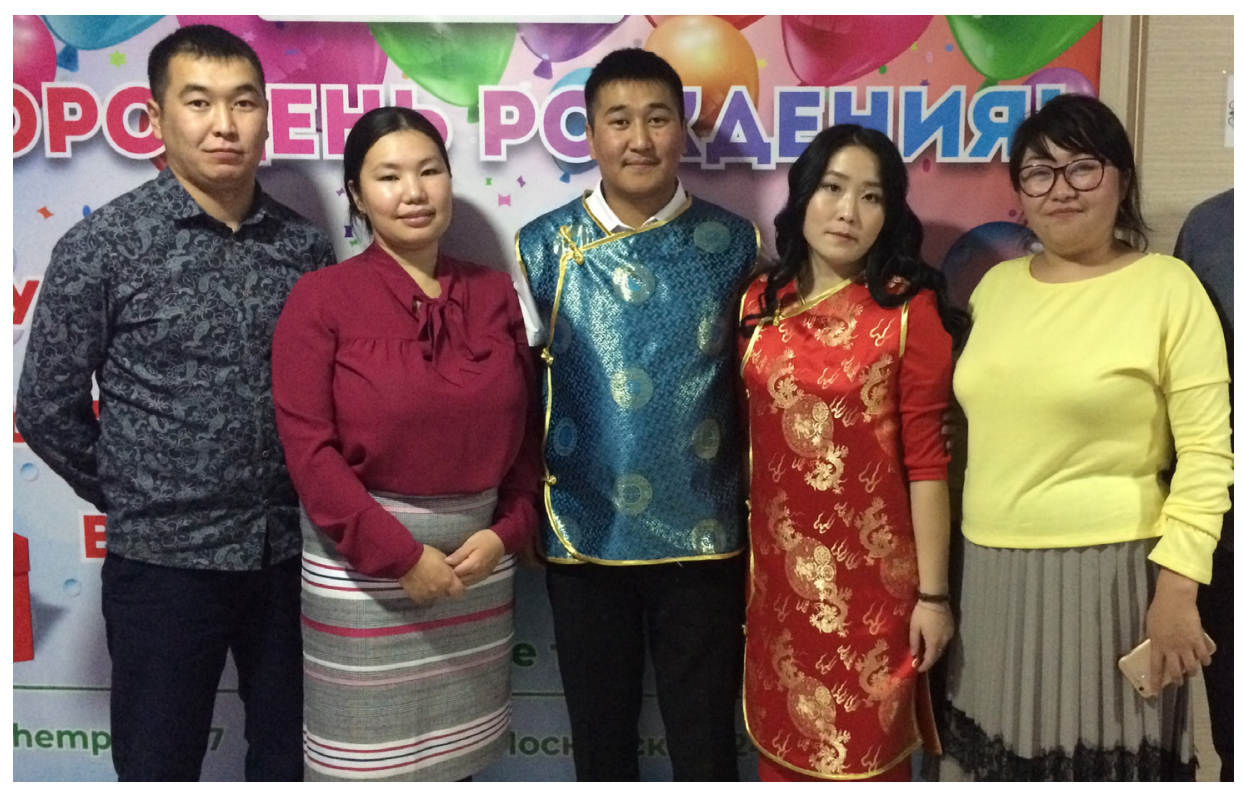

Фото 4. Слева направо: Н. Ю. Кужугет, Ш. Ю. Кужугет, Т. Ю. Кужугет и его жена Ш. Р. Дыртык-оол, Ш. Ю. Кужугет. 2018 г. Фото из личного архива автора. Photo 4. From left to right: N. Yu Kuzhuget, Sh. Yu. Kuzhuget, T. Yu. Kuzhuget and his wife Sh. R. Dyrtyk-ool, Sh. Yu. Kuzhuget in 2018. Photo from the author's personal archive. 
«50 лет СССР» с. Межегей до 1993 г., затем до 1995 г. в совхозе «Кара-Булун» с. Успенка Тандинского района. С 1995 г. начался распад совхоза «Кара-Булун» и в том же году после смерти отца, моя мама осталась без работы. Распад СССР и реформы 1990-х годов привели в том числе и к распаду совхозов в Туве (Севек, Тайбыл, Даржаа, 2020).

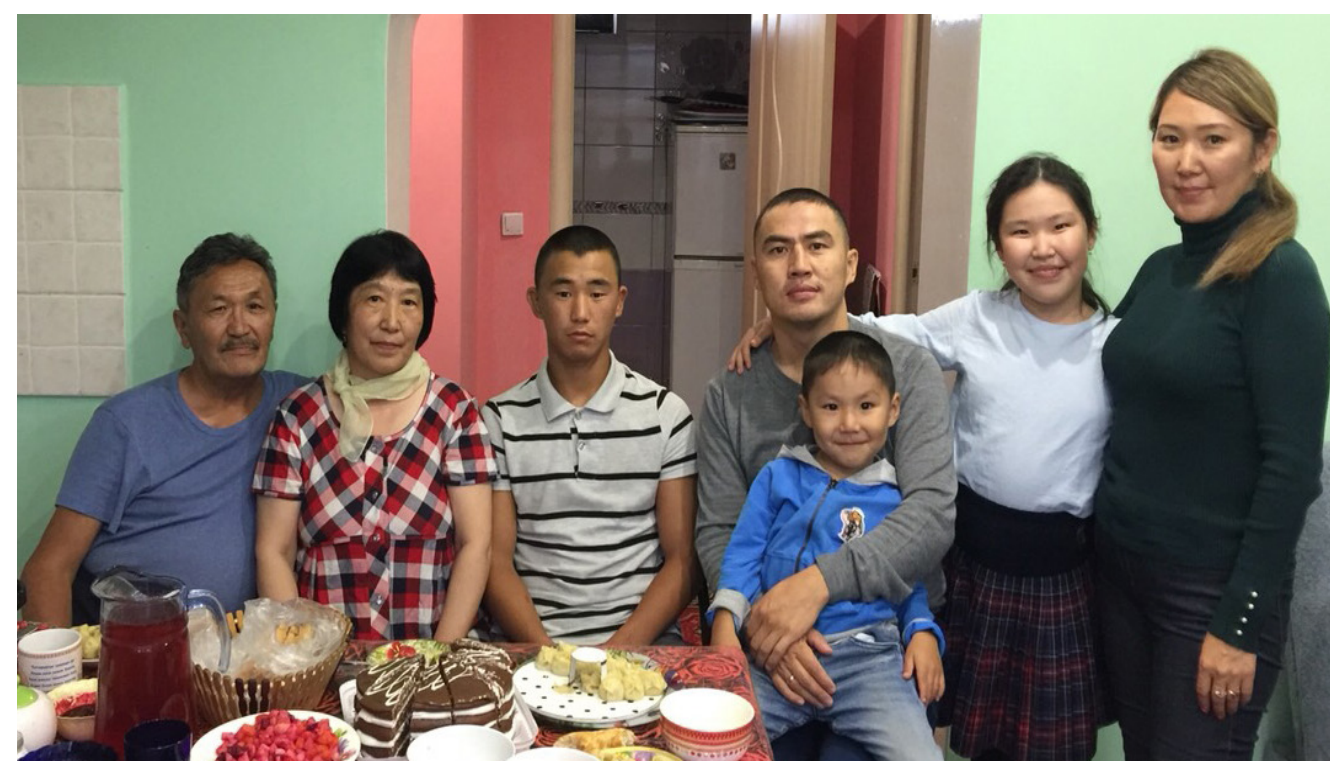

Фото 5. Семья тети А. Д. Соян, 2019. Фото В. Ондар.

Photo 5. The family of aunt A. D. Soyan, 2019. Photo by V. Ondar.

После распада совхоза в с. Межегей родные сестры матери остались там жить. Наша семья в 1995 г. после смерти отца из с. Успенка вернулась в с. Межегей. Мои родители имеют четверых детей: Кужугет Шораана Юрьевна (26.08.1985 г.р.), я, Кужугет Шенне Юрьевна (09.12.1987 г.р.), Кужугет Тойнур Юрьевич (08.08.1989 г.p.), Кужугет Начын Юрьевич (30.04.1992 г.р.). Мы жили и учились в с. Межегей до 2002 г.

В 2002 г. после смерти нашей матери старшими родственниками было принято решение, чтобы меня и младшего брата Начына взяла под опеку тетя Соян Алефтина Доржубаловна (9 на рис. 2) в с. Кызыл-Мажалык. А младшего брата Тойнура взял под опеку дядя Хомушку Александр Доржуевич (8 на рис. 2), который жил со своей семьей в с. Барлык. Моя старшая сестра Кужугет Шораана Юрьевна осталась в с. Межегей, чтобы окончить 11 класс. Она проживала в школе-интернате, уже заканчивала школу и собиралась поступать в высшее учебное заведение.

Разделение места проживания родственников төрел бөлүк кужугет на два района повлияло на взаимоотношения родственников. Они отдалились и стали реже общаться. Только старшие родственники виделись изредка на различных праздничных торжествах.

В настоящее время все родственники из БарунХемчика уже живут в Кызыле, а также в г. Ак-Довураке, Кызыл-Мажалыке, Барлыке. С 2008 г. семья старшей дочери тети Нины Доржуевны Ай-Суу Сарыглар живет и работает в г. Москве. Дети и внуки моих родственников, которые жили в Тандинском районе, тоже стали переезжать в город Кызыл на постоянное место жительства.

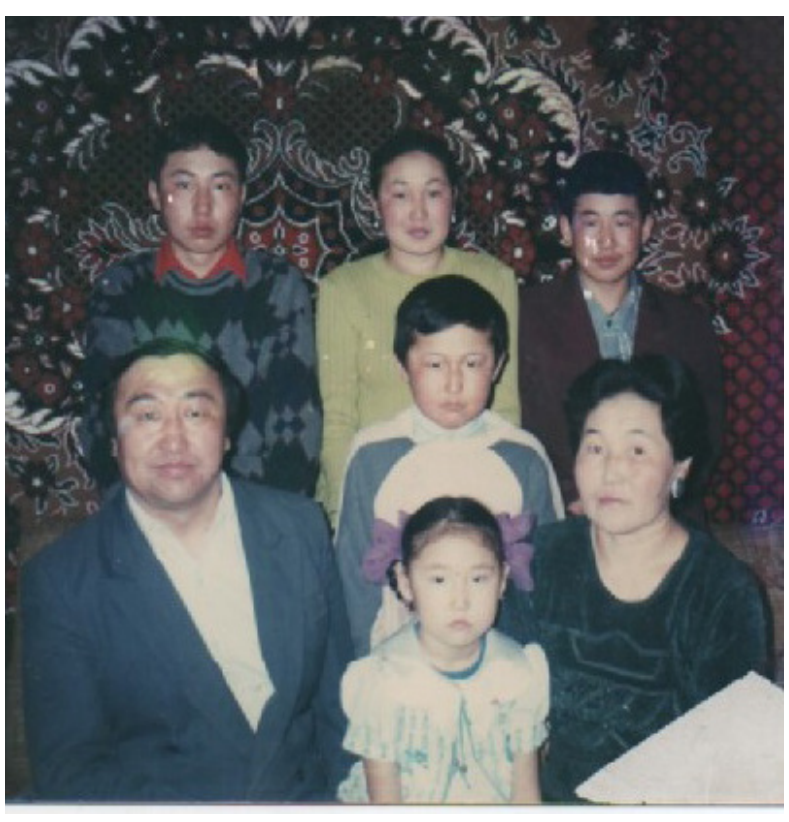

Фото 6. Семья дяди А. Д. Хомушку, 1999. Фото из семейного архива А. Д. Хомушку. Photo 6. The family of uncle A. D. Khomushku, 1999. Photo from the Khomushku family's archive. 
Итак, теперь значительная часть родственников живет в г. Кызыле, остальные в трех селах Бай-Хаак, Успенка, Межегей Тандинского района. Также мои родные стали осваивать и территории за пределами Тувы: в 2021 г. дочь моей тети Раисы Кан-ооловны Шончалай Ооржак стала работать медицинской сестрой в ГБУЗ «Магаданская областная больница» г. Магадан Магаданской области; внучка моей тети Александры Кан-ооловны Ай-Кыс Ойбаа работает в частной медицинской клинике г. Москве; в конце 2021 г. внук тети Александры Кан-ооловны Ангыр Ооржак переехал с семьей в г. Тюмень, стал работать бурильщиком в ООО «Альтобур».

Так, если в советское время члены нашей родственной группы жили на два района Тувы, то в постсоветское время география стала более широкой и стала включать не просто столицу и несколько районов, но и другие российские территории, в том числе столицу России и северные районы. Тем не менее, интенсивность родственных взаимоотношений стала больше.

\section{Роль обряда дагылга}

С 2000-х гг. одним из важнейших мероприятий для поддержания родственных связей тувинцев стал обряд дагылга - освящения природных объектов на территории бывших родовых мест. Тувинцы проводят эти обряды с наступлением теплого времени - весной и летом (хотя иногда встречаются и осенние сборы).

Видов дагылга бывает много. Например, М. Б. Кенин-Лопсан насчитал девять видов дагылга (КенинЛопсан, 1994). Мои родственники проводят такой вид, как суг бажы дагылгазы - обряд освящения водного источника. Как пишет Ч. К. Ламажаа, обряд, который проводит родовое объединение, родственная группа дает его участникам чувство единения, которое важно и для старших, и для младших поколений. Первые получают возможность увидеться, обменяться воспоминаниями, новостями и договориться о помощи друг другу, своим детям и внукам, вторые - узнать новых родственников, показать себя и новых членов семьи (Ламажаa, 2021b: 136). Главным назначением родового обряда дагылга (в отличие от территориальных обрядов, где участвуют жители одного или нескольких поселений) является обращение к предкам, чтобы получить у них благословение; чтобы у всех потомков было крепкое здоровье и благополучие, чтобы в делах сопутствовала удача. И кроме того, на обряде дагылга важным считается представлять родственникам новых членов - зятьями, невестками, новорожденными.

Члены двух родственных групп хомушку и кужугет проводят отдельные дагылга на двух территориях - в Барун-Хемчикском и Каа-Хемском. Кужугеты, хоть они живут в Тандинском районе, проводят дагылга в Каа-Хемском районе, поскольку шаман сказал, что их предки жили именно на территории Каа-Хемского района.

В 2020-2021 гг. я также приняла участие в этих обрядах в обоих случаях. Подробные описания этих дагылга вошли в научно-популярную книгу «Дагылга: тувинские обряды освящения в XXI в.» (Дагылга: тувинские ..., 2021).

Члены төрел бөлүк хомушку проводят суг бажының дагылгазы - освящение истока родника КараСуг в местечке Устуу-Шыдаяк Барун-Хемчикского района. Данное место считается родовой землей их родителей и предков. По словам старейшины рода Александра Доржуевича Хомушку:

«Үстүү-Шыдаякка суг бажының дагылгазын кажан эрттирип эгелээнин сагынмас-дыр бис. Чылдыњ-на дагылганы эрттирерин кызып турар бис, ынчалза-даа чамдык үелерде 3 чыл дургаар эрттирбейн-даа баар таварылгалар бар. Мында бистиң ада-өгбелеривистињ, ада-иевистиң төрээн чери-дир, маңаа бистињ чашкы болгаш элээди үевис эрткен. Ада-иевистиң биске арттырып каан езу-чаңчылдарын кадагалап чоруур ужурлуг бис» - «Мы, дети, практически не помним, когда начали проводить суг бажы дагылгазы в местечке УстууШыдаяк. Периодически проводим обряд освящения истока родника, но были и такие времена, когда в течение трех лет не проводили обряд. Здесь расположена земля наших родителей, наших предков, в этом месте прошли наши детство и юность. Мы обязаны сохранять и чтить обряды и обычаи наших родителей».

А члены моей төрел бөлүк кужугет проводят суг бажы дагылгазы - освящение истока родника Кара-Суг в местечке Кок-Тей Каа-Хемского района. Каждый год всего в обряде суг бажы дагылгазы принимают участие дети и внуки трех родных сестер Ооржак Александры Кан-ооловны (5 на рис. 1), Кужугет Раисы Кан-ооловны (6 на рис. 1), Кужугет Анны Кан-ооловны (7 на рис. 1) с общим количеством 40-50 человек. Старейшиной сбора является Александра Кан-ооловна, которая открывает и закрывает мероприятие. 
По словам моей тети Антониды Кок-ооловны:

«Шаг шаанда кырган-авамның ада-иези Каа-Хем кожууга бай-шыырак, хөй мал-маганныг чурттап чораан. Кайы-даа хамнарга киреривиске, силерниң өгбелериңерниң чурттап чораан чери бо-дур дээн. Ол черге кара суг дагыыр болза эки дээн. Ынчангаш бо черни шилип алгаш, төрелдер дагып турарывыс бо» - «С давних времен в Каа-Хемском районе жили наши предки, родители моей бабушки. Они жили богато, и у них было много скота. Мы спрашивали у шаманов, которые твердили, что надо провести обряд освящения кара суг на земле предков. Поэтому моими родственниками выбрано данное место, и ежегодно проводим суг бажы дагылга».

В этом году к обряду дагылга төрел бөлүк кужугет впервые присоединилась дочь Стал-оола Кан-оола Кужугетовича - Кара-Сал Сайхо Кан-ооловна вместе со своим сыном Кара-Сал Аюшом Андреевичем (2004 г.р.). По словам моей тети, Сайхо Кан-ооловны:

«Меңээ Каа-Хем кожуунда суг бажы дагылгазы эрттирип турарын дунмам Антонида Кок-ооловна чугаалады. Ынчангаш бо 2021 чылда бир дугаар ачамның (Стал-оол Кан-оол Кужугетович) төрелдериниң эрттирип турар дагылгазынга киржир аргалыг болдум. Оон аңгыда келген ужурум болза ачамның төрелдеринге оглум Аюш Кара-Салды (2004) таныштырып, эдержип чорзун дээш эдертип алган мен» «Мне при встрече рассказала моя сестра Антонида Кок-ооловна о том, что они проводят суг бажы дагылгазы в Каа-Хемском районе. Поэтому в этом году, в 2021 году, впервые смогла принять участие в дагылга, который проводил родственники со стороны моего отца. Также моей целью было познакомить своего сына Кара-Сала Аюша с родственниками со стороны дедушки».

Так, две родственные группы хомушку и кужугет, потомки одного предка, проводят родовые обряды дагылга автономно друг от друга в двух разных районах. При этом молодые тувинцы имеют возможность выбирать, присоединяться и к той, и к другой группе и обряду. Так, например, я принимаю участие в обоих дагылга. Мой интерес к дагылга родственной группы хомушку был связан с предложением моей тети Соян Алефтины Доржубаловны, чтобы увидела и помнила землю своих предков, где жили и выросли мои родители.

Никто не помнит, когда восстановила обряд дагылга родственная группа хомушку, но в настоящее время потомки наших предков стараются проводить ежегодно, только иногда через 3 года. Родственная группа кужугет, члены которой проживают в Тандинском районе, начали проводить обряд дагылга с 2014 г., но ежегодным он стал только с 2018 г.

Обряды, которые проводятся как сборы (чыыштар) родственных групп, были направлены на восстановление как самих родственных связей, ослабевших во второй половине ХХ в., так и связи моих родных с местами предков. И регулярность проведения обрядов, а также появившийся интерес родственников из двух групп к обрядам друг друга позволяют предположить о том, что укрепление родственных связей будет продолжаться.

\section{Онлайн-пространство родственных связей}

Совсем недавно впервые в тувиноведении Ч. К. Ламажаа проанализировала новую форму связи тувинцев с родственниками - через социальные сети и мессенджеры. Как показало ее исследование, значительное число тувинцев имеют группы (родственников, коллег, друзей) в мессенджерах, прежде всего в Viber, общение в которых имеет различные социальные последствия, в том числе укрепление и развитие родственных связей и отношений (Ламажаа, 2021a).

Это же онлайн-пространство оказалось освоено и моим төрел бөлүк. С самого начала появления мессенджера Viber в Туве, примерно в 2016 г., в нем были созданы отдельные группы моих родственников. Члены төрел бөлүк хомушку и төрел бөлүк кужугет имеют две разные группы. Участниками обеих групп являются моя сестра Шораана, брат Тойнур и я.

Группа төрел бөлүк хомушку в мессенджере называется «Төрелдер Алаш» («Родственники из Алаш»), которая указывает откуда они родом. В группе около 47 участников, в основном, это дети и внуки Хомушку Доржу Бак-Караевича. Члены данной группы в основном в чате поздравляют друг друга со значимыми праздничными датами: день рождения, юбилеи, Новый год, 8 марта, 23 февраля. Родственная группа кужугет, которые переехали и проживают в Тандинском районе, имеют общую группу «төрелдер. Таңды» («Родственники из Танды»). В группе около 35 участников, в основном это внуки Кужугета Каноола Дамдын-Суруновича. Например, в самые важные моменты жизни членов родственной группы (куда ‘свадьба’, орнукшудулга ‘похороны’, уруг айтырар ‘сватовство невесты’) старшие участники группы призывают всех собирать материальную помощь, средства, подарки. Обычно с подобным объявлением 
в верхней части группы в чате прикрепляется номер телефона, привязанный к чьему-то банковскому счету, на который всем следует переводить денежные средства. Например, при подготовке мероприятия уруг айтырар 'сватовство невесты' (15.07.2021) внука Александры Кан-ооловны Айырана Ооржака члены родственной группы также организованно перевели деньги на указанный номер. Но в связи с ухудшением эпидемиологической ситуации в республике дату мероприятия перенесли. После того как позже мероприятие состоялось, 14 августа 2021 года, на завтрашний день еще раз их поздравляли в данной группе. Также с праздничных мероприятий, подобных этому, родные любят отправлять фото и видео, снятые на смартфоны, в данную группу. В группах родственников «Төрелдер. Алаш» и «Төрелдер. Таңды» также обсуждалось и организация, и проведение обрядов дагылга.

Помимо упомянутых двух чатов родственников, я также состою и в группе «Родные мои», где участниками являются моя старшая сестра Кужугет Шораана Юрьевна, братья Кужугет Тойнур Юрьевич, Кужугет Начын Юрьевич и жена брата Тойнура - Шенне Радиковна Дыртык-оол (1989 г.р.) - всего пять человек. Мы каждый день обмениваемся сообщениями о том, у кого как прошел день, делимся фотографиями рабочих будней, часто делимся фотографиями и видео своих детей. Иногда брат просит меня, жительницу Кызыла, купить ему какие-то вещи и отправить в район, чтобы самому не ехать в город. Например, брат Тойнур летом мастерил пристройку к своему дому с. Кызыл-Мажалык. Когда он выбирал на сайте железную входную дверь, то присылал фото выбранного варианта в нашу группу, а мы, в свою очередь, купили это изделие и отправили ему в район.

Данные примеры приводятся для того, чтобы показать интенсивность общения родственников, и не только для общения, но и координации усилий, хозяйственных дел. Все это помогает нам ощущать и использовать родственные связи, чувствовать поддержку родных.

Общение в трех группах ведется только на тувинском языке. Родственники, которые живут и работают за пределами Тувы, знакомят участников группы с окружающей природой своего места жительства, присылают фотографии, в том числе детей. Если кто-то из родственников умирает, то первым делом пишут в общую группу. Все выражают соболезнования, потом назначают ответственного человека, который собирает денежные средства. Иногда в группах рекламируют свою продукцию, например, чай собственного производства.

Таким образом, онлайн-пространство оказалось чрезвычайно удобным для поддержания, укрепления родственных связей моих родственных групп вне зависимости от места проживания людей.

\section{Заключение}

Так, в статье представлена история төрел бөлүк кужугет - родственной группы кужугетов - тувинцев, родовыми местами которых были места Алаш в Барун-Хемчикском районе Тувы. Исторические перипетии XX века привели к тому, что потомкам одного рода пришлось разъехаться сначала на два района, затем на несколько и даже за пределы Тувы. В целом родственная общность разделилась на четыре родственные группы: Хомушку, Кужугет, Бичен-оол, Стал-оол. Факторами раздела стали факты усыновления/удочерения, во время которых людям менялись родовые имена, паспортизация, которая в целом поменяла данные родных людей, внутренняя и внешняя миграции тувинцев.

Но, тем не менее, сегодня имеются возможности для восстановления родственных связей разделившихся ветвей одного генеалогического древа. Эти возможности предоставляют различные обряды (дагылга, куда и пр.), на которых можно родственникам объединяться, а также онлайн-пространство, которое может соединять людей в режиме онлайн вне зависимости от территории нахождения.

\section{Благодарности}

Автор благодарит за помощь в уточнении данных родственников: Александра Доржуевича Хомушку, Алефтину Доржубаловну Соян, Александру Доржуевну Куулар, Нину Доржуевну Сарыглар, Долаану Доржуевну Монгуш, Саиду Чылбак-ооловну Хомушку, Антониду Кок-ооловну Кужугет, Сайхо Канооловну Кара-Сал, Саиду Доржуевну Хомушку. 


\section{СПИСОК ЛИТЕРАТУРЫ}

Белков, П. Л. (2013) Австралийские системы родства. Основы типологии и элементарные преобразования. СПб. : Наука. 156 с.

Бурыкин, А. А., Попов, В. А. (2020) Русская терминология родства и свойства: историческая динамика, аксиологические поля, коммуникативный дискурс. СПб. : Петербургское Востоковедение. 320 с.

Биче-оол, С. М. (2018) Традиционные брачно-семейные отношения у тувинцев и их трансформация в советский период. Абакан : Журналист. 128 с.

Вайнштейн, С. И. (1959) Род и кочевая община у восточных тувинцев (XIX - начало XX в.) // Советская этнография. № 6. С. $80-86$.

Вайнштейн, С. И. (1961) Тувинцы-тоджинцы. М. : Издательство восточной литературы. 218 с.

Вайнштейн, С. И. (1969) Происхождение и историческая этнография тувинского народа : автореф. дис... д. и. н. M. 45 с.

Вайнштейн, С. И. (2009) Загадочная Тува. М. : ООО «Домашняя газета». 415 с. 188 c.

Дагылга: тувинские обряды освящения в XXI веке (2021) / под ред. Ч. К. Ламажаа и Н. Д. Сувандии. Кызыл : б. и.

Дыртык-оол, А. О., Хертек, С. С. (2018) Родоплеменная группа Кужугет Бай-Тайгинского района Тувы // Лучшая научно-исследовательская работа 2018: сборник статей XII Международного научно-практического конкурса / под ред. Н. Ю. Гуляева. Пенза : Издательство МЦНС «Наука и просвещение». 352 с. С. 80-83.

Кара-оол, Л. С. (2004) Термины родства и свойства в тувинском языке: автореф. дисс. ... к-та филол. н. М., 24 с.

Кара-оол, Л. С. (2006) Термина родства и свойства в тувинском языке. Кызыл : РИО ТывГУ. 252 с.

Кенин-Лопсан, М. Б. (1994) Тыва чоннуң бурунгу ужурлары [Традиционная этика тувинцев]. Кызыл : Издательство «Новости Тувы». 191 с.

Кон, Ф. Я. (1934) За пятьдесят лет: Собрание сочинений: в 3 т. М. : Изд-во Всесоюз. об-ва политкаторжан и ссыльно-поселенцев; тип. Профиздата. Т. 3. Экспедиция в Сойотию. 293 с.

Крецер, И. Ю. (2016) В поисках родства: к постановке проблемы изучения родственных отношений в современных западных исследованиях // Журнал социологии и социальной антропологии. Т. 19. № 1. С. $166-180$.

Кужугет, А. К. (2016) Духовная культура тувинцев: структура и трансформация. Красноярск : Офсет. 320 с.

Кужугет, Ш. Ю., Сувандии, Н. Д., Дамбаа, Ш. В., Ламажаа, Ч. К. (2019) Концепт төрел 'родственник’ в языковой картине мира тувинцев //Новые исследования Тувы. № 3. C. 149-157.DOI: https://www.doi.org/10.25178/nit.2019.3.12

Ламажаа, Ч. К. (2013) Архаизация общества: тувинский феномен. М. : ООО «Книжный дом «ЛИБРОКОМ». 272 с.

Ламажаа, Ч. К. (2017) Проблемы определения и исследования субэтнических групп тувинцев // Новые исследования Тувы. № 1. С. 4-21. DOI: https://www.doi.org/10.25178/nit.2017.1.1

Ламажаa, Ч. К. (2021a) Социальная культура тувинцев и онлайн-пространство // Новые исследования Тувы. No 2. C. 115-129. DOI: https://www.doi.org/10.25178/nit.2021.2.10

Ламажаа, Ч. К. (2021b) Тувинские обряды дагылга в XXI веке // Этнографическое обозрение. № 2. С. 125-143.

Ламажаа, Ч. К., Намруева, Л. В. (2018) Субэтнические дифференциации российских этносов (на примере калмыков и тувинцев) // Новые исследования Тувы. № 2. С. 206-226. DOI: https://www.doi.org/10.25178/nit.2018.2.11

Маннай-оол, М. Х. (2004) Тувинцы: происхождение и формирование этноса. Новосибирск : Наука. 166 с.

Миличич, Б. (2010) Изучение родства, символическое мышление и преистория в антропологии XXI века / пер. с анг. С. Церна // Stratum plus. Археология и культурная антропология. № 2. С. 15-21.

Очерки социального развития Тувинской АССР (1983) / Бойко В. И., Белошапкина В. Н., Ширшин Г. Ч. и др. / под ред. Ю. Л. Аранчына. Новосибирск : Наука. 262 с.

Потапов, Л. П. (1969) Очерки народного быта тувинцев. М. : Наука. 400 с.

Прокофьева, Е. Д. (2011) Процесс национальной консолидации тувинцев. СПб. : Наука. 538 с.

Пчелов, Е. В. (2000) Теоретические понятия генеалогии // Гербовед. № 45. С. 54-61.

Севек, В. К., Тайбыл, Р. С., Даржаа, Ч. Б. (2020) Анализ экономической эффективности типовых этнических хозяйств Республики Тыва // Научные труды Вольного экономического общества России. Т. 223. № 3. С. $468-477$.

Старикова, Г. И. (2021) Локальная история и генеалогия (на примере казачьего рода Заварухиных из станицы Магнитной) // Генеалогия и архивы: материалы третьей Всероссийской научно-практической конференции / отв. науч. ред. Н. А. Антипин. Челябинск : Государственное учреждение «Объединенный государственный архив Челябинской области». 427 с. С. 384-390.

Степанофф, Ш. (2009) Метаморфозы родства у тувинцев // Этнографическое обозрение. № 4. С. $129-145$.

Сувандии, Н. Д. (2011) Тувинская антропонимия. Кызыл : РИО ТывГУ. 208 с. 
Татаринцев, Б. И. (2009) О некоторых тувинских этнонимах // Татаринцев Б. И. Избранные научные труды. Кызыл : ГУП РТ «Тываполиграф». 287 с. С. 164-169.

Чистик, Ж. К. (2010) Экологическая культура тувинского этноса / отв. ред. С. С. Курбатская. Кызыл : Тувинское книжное издательство. 176 с.

Яковлев, Е. К. (1900) Семейный и общественный быт у сойот: роды, степени родства, брак и положение женщины, развод, население, похороны // Этнографический обзоръ инородческаго населенія долины Южного Енисея и объяснительный каталогъ этнографического отдела музея. Минусинск, 1900. Вып. 4.

Read, D. W. (2007) Kinship Theory: A Paradigm Shift // Ethnology. № 46(4). P. 329-364.

Read, D. W. (2009) Another look at kinship: reasons why a paradigm shift is needed // Алгебра родства / отв. ред. В. А. Попов. СПб. : МАЭ РАН. Вып. 12. Р. 42-69.

Дата поступления: 12.09.2021 2.

\section{REFERENCES}

Belkov, P. L. (2013) Avstraliiskie sistemy rodstva. Osnovy tipologii i elementarnye preobrazovaniia [Australian kinship systems. Basics of typology and elementary transformations]. St. Petersburg, Nauka Publ. 156 p. (In Russ.).

Burykin, A. A. and Popov, V. A. (2020) Russkaia terminologiia rodstva i svoistva: istoricheskaia dinamika, aksiologicheskie polia, kommunikativnyi diskurs [Russian terminology of kinship and properties: Historical dynamics, axiological fields, communicative discourse]. St. Petersburg, Peterburgskoe vostokovedenie Publ. 320 p. (In Russ.).

Biche-ool, S. M. (2018) Traditsionnye brachno-semeinye otnosheniya u tuvintsev i ikh transformatsiya $v$ sovetskii period [Traditional matrimonial and family relations among the Tuvans and their transformation during the Soviet era]. Abakan, Zhurnalist Publ. 125 p. (In Russ.).

Weinstein, S. I. (1959) Rod i kochevaia obshchina u vostochnykh tuvintsev (XIX - nachalo XX v.) [The clan and nomadic community of the Eastern Tuvans (19th - early 20th century)]. Sovetskaia etnografiia, no. 6, pp. 80-86. (In Russ.).

Weinstein, S. I. (1961) Tuvintsy-todzhintsy. Istoriko-etnograficheskie ocherki [Tozhu Tuvans: Historical and ethnographic essays]. Moscow, Nauka Publ. 218 p. (In Russ.).

Weinstein, S. I. (1969) Proiskhozhdenie i istoricheskaia etnografiia tuvinskogo naroda [The origin and historical ethnography of the Tuvan people]: Abstract of the diss.... Doctor of History. Moscow. 45 p. (In Russ.).

Weinstein, S. I. (2016) Zagadochnaia Tuva [The mysterious Tuva]. Moscow, Domashniaia gazeta Publ. 416 p. (In Russ.)

Dagylga: tuvinskie obriady osviashcheniia $v$ XXI veke [Dagylga: Tuvan rites of consecration in the 21st century] (2021) / ed. by Ch. K. Lamazhaa and N. D. Suvandii. Kyzyl, s. n. 188 p. (In Russ. and Tuv.).

Dyrtyk-ool, A. O. and Khertek, S. S. (2018) Rodoplemennaia gruppa Kuzhuget Bai-Taiginskogo raiona Tuvy [The indigenous group of Kuzhuget in the Bai-Taiginsky district of Tuva]. In: Luchshaia nauchno-issledovatel'skaia rabota 2018 [The best research works of 2018]: A collection of articles of the 12th International research-to-practice competition / ed. by N. Yu. Guliaev. Penza, Publishing House of the International Center for Scientific Cooperation "Nauka i prosveshchenie”. 352 p. Pp. 80-83. (In Russ.).

Kara-ool, L. S. (2004) Terminy rodstva i svoistva $v$ tuvinskom iazyke [Kinship and in-law terms in the Tuvan language] : Abstract of the Diss.... Candidate of Philology. Moscow. 24 p. (In Russ.).

Kara-ool, L. S. (2006) Terminy rodstva i svoistva $v$ tuvinskom iazyke [Kinship and in-law terms in the Tuvan language]. Kyzyl, Editorial and Publishing Department at Tuvan State University. 252 p. (In Russ.).

Kenin-Lopsan, M. B. (1994) Tyva chonnuщ burungu uzhurlary [Traditional ethics of Tuvans]. Kyzyl, Novosti Tuvy Publ. 192 p. (In Tuv.).

Kon, F. Ya. (1934) Za piat'desiat let [In fifty years] : Collected works : [in 3 vols.]. Moscow : Publishing House of the All-Union Society of Political Prisoners and Exiled Settlers. Vol. 3: Ekspeditsiia v Soiotiiu [An expedition to Soyotia]. 293 p. (In Russ.).

Kretser, I. Yu. (2016) V poiskakh rodstva: k postanovke problemy izucheniia rodstvennykh otnoshenii v sovremennykh zapadnykh issledovaniiakh [Searching for kinship: Towards a problem statement in contemporary western kinship studies]. The Journal of Sociology and Social Anthropology, vol. 19, no. 1, pp. 166-180. (In Russ.).

Kuzhuget, A. K. (2006) Dukhovnaia kul'tura tuvintsev. Struktura i transformatsiia [The immaterial culture of Tuvans. Structure and transformation]. 2nd ed., enlarged. Krasnoyarsk, Ofset Publ. 320 p. (In Russ.).

Kuzhuget, Sh. Yu., Suvandii, N. D., Dambaa, Sh. V. and Lamazhaa, Ch. K. (2019) Kontsept törel 'rodstvennik' v iazykovoi kartine mira tuvintsev [The concept of төрел ('relative') in the Tuvan linguistic world picture]. New Research of Tuva, no. 3, pp. 149-157. (In Russ.). DOI: https://doi.org/10.25178/nit.2019.3.12 
Lamazhaa, Ch. K. (2013) Arkhaizatsiia obshchestva. Tuvinskii fenomen [Archaization of the society. Tuvan phenomenon]. Moscow, Knizhnyi dom “Librokom”. 272 p. (In Russ.)

Lamazhaa, Ch. K. (2017) Problemy opredeleniia i issledovaniia subetnicheskikh grupp tuvintsev [Sub-ethnic groups of the Tuvans : problems of definition and research]. New Research of Tuva, no. 1, pp. 4-21. (In Russ.). DOI: https://doi. org/10.25178/nit.2017.1.1

Lamazhaa, Ch. K. (2021a) Sotsial'naia kul'tura tuvintsev i onlain-prostranstvo [Social culture of Tuvans and online space]. New Research of Tuva, no. 2, pp. 115-129. (In Russ.). DOI: https://doi.org/10.25178/nit.2021.2.10

Lamazhaa, Ch.K.(2021b) Tuvinskie obriady dagylga vXXI veke [Tuvan rites dagylga in the 20th century]. Etnograficheskoe obozrenie, no. 2, pp. 125-143. (In Russ.). DOI: https://doi.org/10.31857/S086954150014811-2

Lamazhaa, Ch. K. and Namrueva, L. V. (2018) Subetnicheskie differentsiatsii rossiiskikh etnosov (na primere kalmykov $\mathrm{i}$ tuvintsev) [Sub-ethnic differentiations of Russian ethnic groups: The case of Kalmyks and Tuvans]. New Research of Tuva, no. 2, pp. 206-226. (In Russ.). DOI: https://doi.org/10.25178/nit.2018.2.11

Mannai-ool M. Kh. (2004) Tuvintsy: proiskhozhdenie i formirovanie tuvinskogo etnosa [Tuvans: The origin and formation of the Tuvan ethnos]. Novosibirsk, Nauka Publ. 166 p. (In Russ.).

Miličić, B. (2010) Izuchenie rodstva, simvolicheskoe myshlenie i preistoriia v antropologii XXI veka [Kinship studies, symbolic thought, and prehistory in the 21st century anthropology]. Stratum Plus, no. 2, pp. 15-21. (In Russ.).

Ocherki sotsial'nogo razvitiia Tuvinskoi ASSR [Essays on social development of the Tuvan ASSR] (1983) / V. I. Boiko, V. N. Beloshapkina, G. Ch. Shirshin et al. ; ed. by Yu. L. Aranchyn. Novosibirsk, Nauka Publ. 262 p. (In Russ.).

Potapov, L. P. (1969) Ocherki narodnogo byta tuvintsev [The Tuvans: Sketches of the folk lifestyle and related household activities]. Moscow, Nauka Publ. 402 p. (In Russ.).

Prokofieva, E. D. (2011) Protsess natsional'noi konsolidatsii tuvintsev [The process of the national consolidation of the Tuvans]. St. Petersburg, Nauka Publ. 538 p. (In Russ.).

Pchelov, E. V. (2000) Teoreticheskie poniatiia genealogii [Theoretical concepts of genealogy]. Gerboved, no. 45, pp. 54-61. (In Russ.).

Sevek, V. K., Taibyl, R. S. and Darzhaa, Ch. B. (2020) Analiz ekonomicheskoi effektivnosti tipovykh etnicheskikh khoziaistv Respubliki Tyva [Analysis of economic efficiency of typical ethnic farms of the Republic of Tuva]. Nauchnye trudy Vol'nogo ekonomicheskogo obshchestva Rossii, vol. 223, no. 3, pp. 468-477. (In Russ.). DOI: https://doi.org/10.38197/20722060-2020-223-3-468-477

Starikova, G. I. (2021) Lokal'naia istoriia i genealogiia (na primere kazach'ego roda Zavarukhinykh iz stanitsy Magnitnoi) [Local history and genealogy (The case of the Cossack family of the Zavarukhins from the village of Magnitnaya)]. In: Genealogiia $i$ arkhivy [Genealogy and archives] : Proceedings of the Third All-Russian research-to-practice conference / ed. by N. A. Antipin. Chelyabinsk, State Institution “United State Archive of the Chelyabinsk Region”. 427 p. Pp. 384-390. (In Russ.).

Stépanoff, Ch. (2009) Metamorfozy rodstva u tuvintsev [Metamorphoses of kinship among Tuvans]. Etnograficheskoe obozrenie, no. 4, pp. 129-145. (In Russ.).

Suvandii, N. D. (2011) Tuvinskaia antroponimiia [Tuvan anthroponymy]. Kyzyl, Editorial and Publishing Department at Tuvan State University. 207 p. (In Russ.).

Tatarintsev, B. I. (2009) O nekotorykh tuvinskikh etnonimakh [About some Tuvan ethnonyms]. In: Tatarintsev B. I. Izbrannye nauchnye trudy [Selected scientific works]. Kyzyl, Tyvapoligraf Publ. 287 p. Pp. 164-169. (In Russ.).

Chistik, Zh. K. (2010) Ekologicheskaia kul'tura tuvinskogo etnosa [Ecological culture of the Tuvan ethnic group]. Kyzyl, Tuvan Book Publisher. 176 p. (In Russ.)

Yakovlev, E. K. (1900) Semeinyi i obshchestvennyi byt u soiot: rody, stepeni rodstva, brak i polozhenie zhenshchiny, razvod, naselenie, pokhorony [Family and social life of the Soyot: Birth, degree of kinship, marriage and status of women, divorce, population and funeral]. In: Yakovlev, E. K. Etnograficheskii obzor inorodcheskogo naseleniia doliny Yuzhnogo Eniseia i ob"iasnitel'nyi katalog etnograficheskogo otdela muzeia [An ethnographic review of the South Yenisei Valley and the explanatory catalogue of the Museum's Ethnography Research Department]. Minusinsk, V. I. Kornakov's Printing House. 357 p. Pp. 79-99. (In Russ.).

Read, D. W (2007) Kinship theory: A paradigm shift. Ethnology, vol. 46, no. 4, pp. 329-364.

Read, D. W. (2009) Another look at kinship: Reasons why a paradigm shift is needed. In: Algebra rodstva [Algebra of kinship]. Issue 12 / ed. by V. A. Popov. St. Petersburg, Museum of Anthropology and Ethnography of RAS. Pp. 42-69.

Submission date: 12.09 .2021$. 